\title{
Physicochemical Characterization of the water of the River Ruki in the Garden of Eala in Democratic Republic of Congo
}

\section{MATONDO FALANGA J. ${ }^{1}$, KALONDA IKANA ${ }^{1}$, , LIKOBA BOLOMBO ${ }^{1}$, KOLOKOTA BAELO ${ }^{2}$, BALIANGA BASUSU $^{3}$., BOBOTO NYABOLONDO ${ }^{4}$ KASONGO KANYINDA $^{5}$ and NGELINKOTO MPIA ${ }^{5}$}

${ }^{1}$ Department of Biology-Chemistry, Chemistry-Physics \& Geography and Management of the Environment, Teaching Higher Institute, Mbandaka, Ecuador

${ }^{2}$ Department of Sciences of the Environment, University of Mbandaka, Ecuador-DR Congo

${ }^{3}$ Higher institute of Techniques Medical

${ }^{4}$ Department of Petro-chemistry and Refining, University of Kinshasa, Kinshasa, DR Congo

${ }^{5}$ Department of Water and Forests, Higher Institute of Fishing, Mbandaka-DR Congo

${ }^{6}$ Department of Chemistry, Teaching University National, Kinshasa, DR Congo

DR Congo

\begin{abstract}
The present study consists with the physicochemical characterization of the water of the Ruki river by the measurement of some physicochemical parameters on six sites of selected sampling of Mars to May 2018.

We studied the effect of some physicochemical parameters which are mainly: temperature, $p H$, electric conductivity, solid substances in suspension, oxygen salinity and rate dissolve.

The measured physicochemical parameters reveal that the quality of water of the Ruki river is still good. Indeed, the temperature is raised a little, oxygen dissolves is in deficit, the self-purification of this river is slow. The solid substances in suspension approach the limiting values for surface waters following an occasional market at the edge of the river in the botanical garden of Eala.
\end{abstract}

Key words: Botanical garden, Physicochemical Characterization, Water Quality, The river Ruki.

\section{INTRODUCTION}

The wetlands represent the best examples of ecosystems from the point of view of their biological functions: biological production, habitat and ecological richness for the animal and vegetable species, the ecological and hydraulic functions and of their importance socio-economic [1].

The fresh waters do not constitute that $2,5 \%$ of all water present on the surface of the ground, whose near total is under ground and in the glaciers. The rivers and the lakes, principal sources of fresh water, do not represent that 0,007 $\%$. the Democratic Republic of Congo east one of countries which have the hydrous potential most abundant in the world. However, this quantity of water available is continuously reduced following a bad management of used, waste water and rains [2].

The Democratic Republic of Congo is rich in wetlands, these mediums make parties of the most invaluable resources in the field of biological diversity and the natural productivity. In order to consider any rational and durable aquacole exploitation, there are many parameters which make it possible to quantify the elements physical or chemical (temperature, salinity, $\mathrm{pH}$, electric conductivity, oxygen dissolves...) in the water of a river, river or lake which require to be followed.

The objective of our study is the determination of some physicochemical parameters of the water of the Ruki river. 


\section{MATERIALS AND METHODOLOGY}

\subsection{Medium of study}

The Ruki river is one of water levels of the Democratic Republic of Congo, passing by the botanical garden of Eala, with a few kilometers of the town of Mbandaka in the province of Ecuador.

The botanical garden of Eala is one of seven zoological gardens and botanical national of the Democratic Republic of Congo.Located in the province of Ecuador, to 7 kilometers in the North-East of the town of Mbandaka, the botanical garden of Eala extends on a surface from 371 ha. It is delimited in North by the Ruki river, in the South by the road of Mbandaka towards the great seminar of Bamanya, in the West by the Bokilimba village and the East by the Boyeka village. It is subject to the influence of the climate equatorial-heat and wet, with an average temperature of 250 Centigrade per annum and a rate of rainfall of 177 Misters and his ground is sablo-argillaceous [3].

The wide one of this garden is made of two parts, the southern part is an entirely wild forest reserve, the northern part is amenagée and includes the botanical, agronomic and horticultural collections.

Moreover, the botanical garden of Eala includes/understands 50 ha of flooded marshes, 50 ha periodically flooded and 7 ha of grassy formation to hyparrhenia.

\subsection{Sampling}

The sampling of water was carried out of Mars to May in 2018 and this, at six stations distributed on the basin of the Ruki river. Several parameters of pollution were measured.

\subsection{Physicochemical analysis}

Parameters physicochemical hereafter: temperature, $\mathrm{pH}$, conductivity, solid substances in suspension, salinity and oxygen dissolve were in situ given on six sites indicated by: R1, R2, R3, R4, R5, R6.

\subsection{Method and statistical processing of data}

We used two probe multi-parameters of mark HANNA of type HI 991300 and HI 9146 for the reading of the various physical and chemical parameters. We started with a prospection of the ground of which the goal is the choice of the sites of taking away of water. The sites of sampling were the subject of the various physical and chemical analyses. The results of the analyses are treated then to draw the conclusions.

The statistical data processing was carried out using Microsoft Office Excel 2016.

\section{RESULTS AND INTERPRETATION}

\subsection{Presentation of the results}

This section has the results obtained during our study. They are physicochemical parameters compared with the international standards [4]. It should be noted that 6 parameters were studied on 6 sites and are gathered in the following table:

Table 1: Parameters of the water of the river Ruki d' Eala

\begin{tabular}{|l|c|c|c|c|c|c|c|}
\hline Parameters & $\mathbf{R}_{\mathbf{1}}$ & $\mathbf{R}_{\mathbf{2}}$ & $\mathbf{R}_{\mathbf{3}}$ & $\mathbf{R}_{\mathbf{4}}$ & $\mathbf{R}_{\mathbf{5}}$ & $\mathbf{R}_{\mathbf{6}}$ & Normes \\
\hline Temperature & 26.9 & 27,9 & 26.9 & 27.2 & 26.9 & 27.1 & $25^{\circ} \mathrm{C}$ \\
pH & 4,27 & 4.27 & 4.23 & 4.33 & 4.24 & 4.28 & $6,5-8,5$ \\
Conductivity & 36 & 36 & 35 & 35 & 35 & 35 & $50-250 \mu \mathrm{s} / \mathrm{cm}$ \\
MES & 18 & 18 & 17 & 17 & 17 & 17 & $25 \mathrm{mg} / \mathrm{L}$ \\
\hline
\end{tabular}


International Journal of Advances in Scientific Research and Engineering (ijasre), Vol 6 (9), September -2020

\begin{tabular}{|l|c|c|c|c|c|c|c|}
\hline Oxygen dissolves & 4,38 & 4.27 & 4.37 & 4.43 & 4.50 & 4.53 & $5-7 \mathrm{mg} / \mathrm{L}$ \\
Salinity & 0 & 0 & 0 & 0 & 0 & 0 & $<1 \mathrm{~g} / \mathrm{L}$ \\
\hline
\end{tabular}

The table I shows the average values of the physicochemical parameters measured for the various sites. This table indicates that the values of various parameters vary from a site with another. Temperature, the $\mathrm{pH}$, oxygen dissolves vary generally site with another. Electric conductivity presents an exception, it is equal to the site R1 and R2 and decreases and then remains constant R3 site with the R6 site; it is the same for the solid matters in suspensions.

The figure below makes it possible to better determine the variations of the various parameters physicochemical taken in various sites of the Ruki river

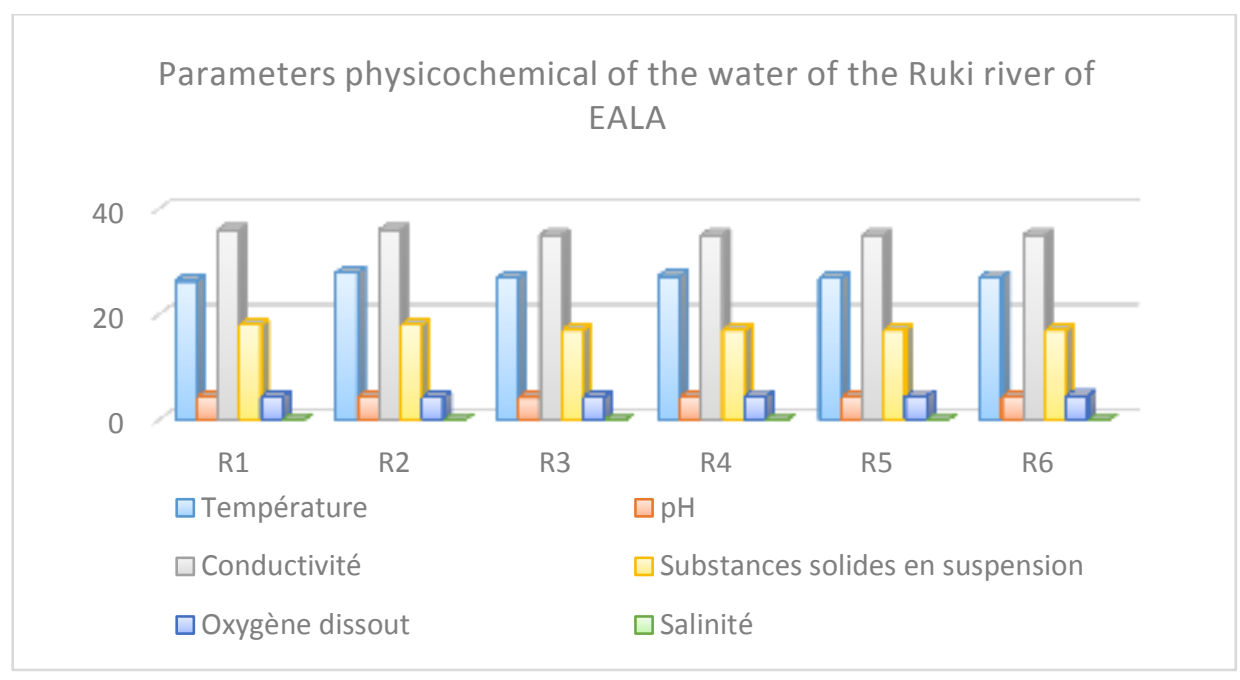

Figure 1:Physicochemical parameters of the various sites of the Ruki river

\subsection{Interpretation of the results}

The results mentioned again in table I, combined with those of figure 1 indicate that the river Ruki d' Eala present:

An average temperature of $26,90 \mathrm{C}$ to the first site, and imbalance starts to be felt with the second site $(27,90 \mathrm{C})$; the other values vary from a site with another. It is advisable to announce that the temperature of water depends primarily on the medium, but it influences the oxygen content dissolves and the multiplication of the watery organizations.

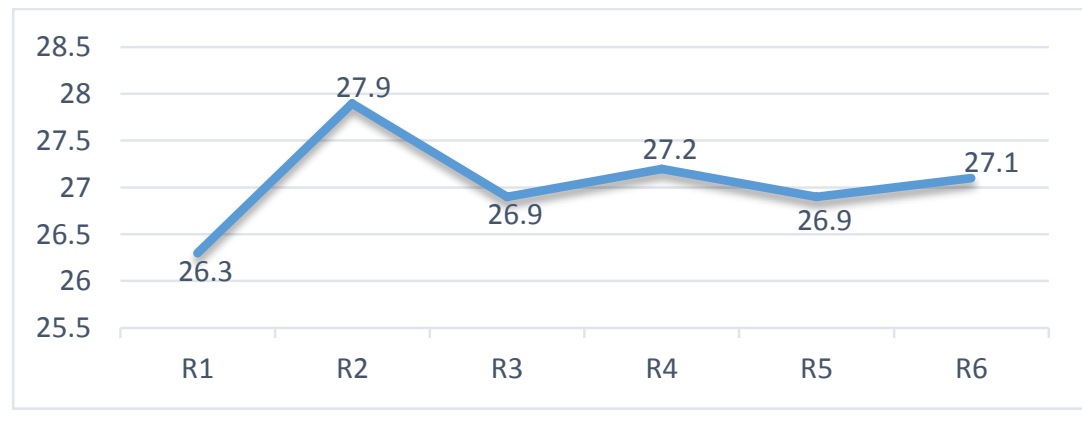

Figure 2: variation of temperature in the various sites

The $\mathrm{pH}$ of the Ruki river varies between 4,23 and 4,33; the standards of $\mathrm{pH}$ for surface waters being of 6,5 and 8,5 (Manituba, 2011), the values of the $\mathrm{pH}$ of water of the Ruki river do not remain in the standards, that affects the watery life of this river and consequently, influence self-purification of the river, and that proves also the presence of the mineral or organic acids in this river. 
International Journal of Advances in Scientific Research and Engineering (ijasre), Vol 6 (9), September -2020

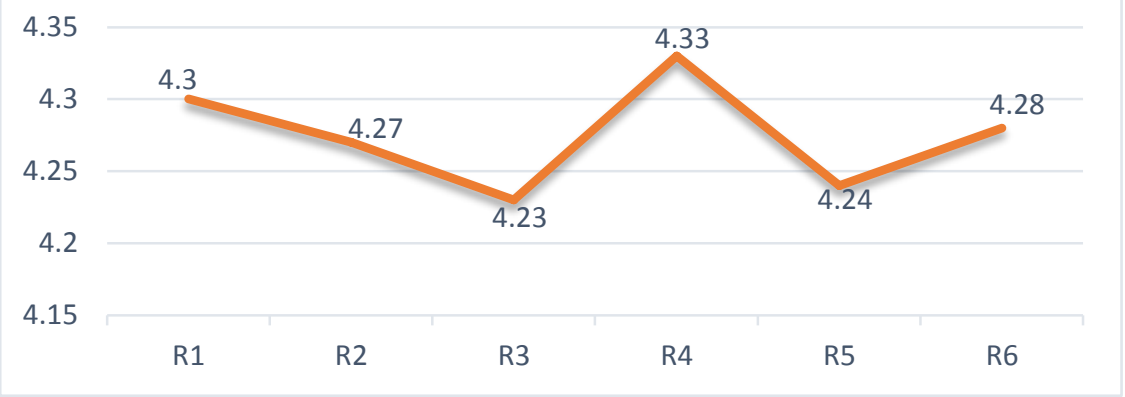

Figure 3: variation of $\mathrm{pH}$ in the various sites

The electric conductivity of the Ruki river varies between 35 to $36 \mu \mathrm{s} / \mathrm{cm}$; these values being lower than the standards for surface waters ( 50 to $250 \mu \mathrm{s} / \mathrm{cm}$ ), that indicates that the total mineralisation of the water of the Ruki river is slow, which predicts a low content of ions.

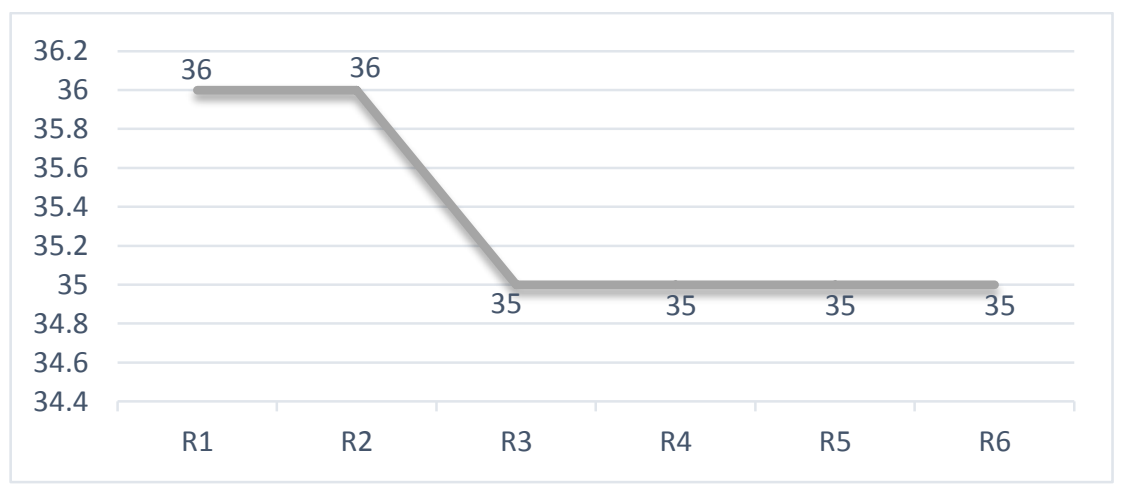

Figure 4: variation of electric conductivitie in the various sites

The rate of oxygen dissolves in the Ruki river varies between 4,27 and 4,53 $\mathrm{Mg}$; oxygen dissolves makes it possible to evaluate the capacities of self-purification of the river via the organizations there alive, it strongly orders the watery life; as the values of the rate of oxygen dissolves are below $5 \mathrm{Mg}$, that translated simply that the Ruki river is disturbed.

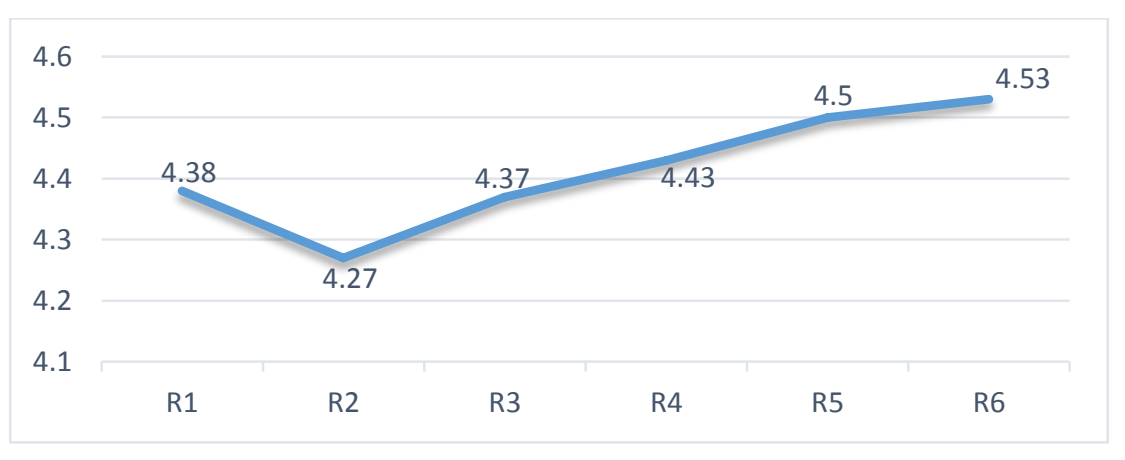

Figure 5: variation of dissolved oxygen content in the various sites

The suspended matter rate in the Ruki river varies between $18 \mathrm{mg} / \mathrm{L}$ and $17 \mathrm{mg} / \mathrm{L}$.

The content of suspended matter of water is very variable according to rivers'. For each one of them, it is a function of the nature of the crossed grounds, of the season, of pluviometry, work and the rejections, etc. In fact, all the rivers contain suspended matter and contents of a few milligrams per liter do not pose major problems. However, of the high contents can prevent the penetration of the light, to decrease oxygen dissolves and to limit the development of the watery life then.[4] 
In the scale of the classification of the state of water according to suspend matter content [5], a solid rate of substances in suspension lower than $25 \mathrm{mg} / \mathrm{L}$ qualifies this water of a very good quality. If one refers of this scale, the water of the Ruki river is of good quality.

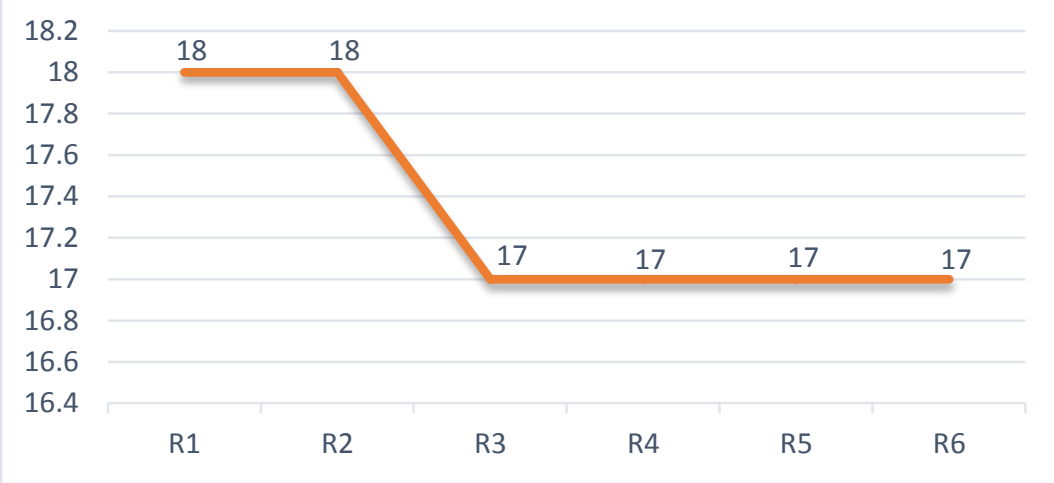

Figure 6: variation of suspended matter content in the various sites

The salinity of the water of Ruki river being equal to $0 \mathrm{~g} / \mathrm{L}$ in all the sites of taking away being subject of our study, that proves that the water of the Ruki river is soft, because so that a water is considered soft, it is necessary that its salinity is lower than $1 \mathrm{~g} / \mathrm{L}$.

\section{GENERAL CONCLUSION}

The present study consists with the physicochemical characterization of the water of the Ruki river by the measurement of some physicochemical parameters on six sites of selected sampling of Mars to May 2018.

To this end, a matrix was studied, namely water. The latter, is regarded as the tank to which are conveyed the majority of the contaminants.

These analyses, reveal that the quality of water of the Ruki river is still good. Indeed, the temperature is raised a little, oxygen dissolves is in deficit, the self-purification of this river is slow. The solid substances in suspension approach the limiting values for surface waters following an occasional market at the edge of the river in the botanical garden of Eala.

Have regard by what precedes, it is advisable that the government is implied personally to seek solutions and to even impose severe rules, to make apply the principle of responsibility to any pollutant to safeguard our national heritage.

\section{REFERENCES}

1. RAMSAR R., (1994), Liste disponible sur le site Internet de la conservation de RAMSAR à l'adresse suivant : http//www.ramsarm.org./key ris type

2. NANITUMA M., (2011). Contribution à l'effort de production et de distribution de l'eau potable en R.D.C : cas de la ville de Kinshasa, Thèse de doctorat en Sciences chimiques, Université de Kinshasa.

3. PYNAERT L., (1957) «Le Jardin d'Eala », Revue Zooléo, n³7, pp 211-223

4. RODIER J., (1976). L'analyse de l'eau. Eau naturelle, eau résiduaire, eau de mer. 5ème edition, Edition Dunod, Paris, France, p 1600.

5. HAMMOUDA N., (2013). Contribution à l'étude de l'effet de l'action anthropique sur les zones humides du Sud-est du Sahara (Cas de l'Oued Righ). Mémoire de master Académique. Université d'Ouargla, pp 19-23.

6. MALIANI K., OTAMONGA J.P., NGELINKOTO P., KABATUSUILA P., MUBEDI ILUNGA J. (2017). Caractérisation physico-chimique de l'eau de la rivière Lukunga dans la ville de Kinshasa (RD CONGO), Larhyss Journal, n²9, pp 121-136.

7. NOUI M. \& TALEB R., (2011). Caractéristiques physico-chimiques et niveau trophique d'un plan d'eau saumâtre (lac Méggarine). Mémoire d'ingénieur d'Etat. Université d'Ouargla.

8. MAKHOUKH M., SBAA M., BERRAHOU A., VAN CLOOSTER M., (2011). Contribution à l'étude physico-chimique des eaux superficielles de l'Oued Moulaya (Maroc Oriental), Larhyss Journal, n09, pp 149-169. 
International Journal of Advances in Scientific Research and Engineering (ijasre), Vol 6 (9), September -2020

9. DOUBI M., DERMAJ A., AIT HADOU B., CHEBABE D, ERRAMLI H., HAJJAJI N., ABDELLAH SRHIRI A., (2013). Contribution à l'étude physico-chimique de l'oued Moulouya et un affluent au niveau de la région d'Outat El Haj, Larhyss Journal, ${ }^{\circ} 16$, pp 91-104.

10. ABDOULAYE DEMBA N'DIAYE, KHADIJETTOU MINT MOHAMED SALEM, MOHAMED OULD SID'AHMED OULD KANKOU, (2012). Contribution à l'étude de la qualité physico-chimique de l'eau de la rive droite du fleuve Sénégal, Larhyss Journal, n¹2, pp 71-83.

11. AMINOT A. \& CHAUSSEPIED M., (1983). Manuel des analyses chimiques en milieu marin, CNEXO, Brest, p 395.

12. BELGHITI M., CHAHLAOUI A., BENGOUMI D., EL MOUSTAINE, (2013). Etude de la qualité physicochimique et bactériologique des eaux souterraines de la nappe plio-quaternaire dans la région de Meknès (Maroc), Larhyss Journal, n¹4, pp 21-36.

13. CLAUDE DEJOUX (1988). La pollution des eaux continentales africaines, Edition Orston, Paris.

14. AMINOT A.\& KEROUEL R., (2004). Hydrologie des écosystèmes marins. Paramètres et analyses. Edition Ifremer, $\mathrm{p} 160$.

15. W.H.O. (1987). Global pollution and health results of related environmental monitoring. Global Environment Monitoring System, WHO, UNEP

16. BAECHLER L., (2012) «La bonne gestion de l'eau : un enjeu majeur du développement durable », L'Europe en Formation. [En ligne], URL:www.cairn.info/revue-l-europe-en-formation-2012-3.

"Corresponding Author: MATONDO FALANGA J juniormatfal@gmail.com 